\title{
USE OF REMOTE-SENSING DATA IN MODELLING RUN-OFF FROM THE GREENLAND ICE SHEET
}

\author{
by
}

\author{
H.H. Thomsen and R.J. Braithwaite
}

(Grønlands Geologiske Undersøgelse, Øster Voldgade 10, DK 1350, København K, Denmark)

\section{ABSTRACT}

Run-off modelling is needed in Greenland to extend the short series of measurements. However, the delineation of hydrological basins on the Greenland ice sheet is difficult because of the lack of information about surface and subglacial drainage patterns. Low Sun-angle Landsat data have been used for mapping local surface features which has led to an improvement in basin delineations and thereby run-off simulations. Work is now in progress to map subglacial topography by electromagnetic reflection (EMR) from a helicopter. This information will be used for calculating hydraulic potentials within the basin and to assess the possibilities of future changes in drainage-basin delineation.

\section{INTRODUCTION}

The possibilities of developing hydroelectric power in Greenland have been investigated since the oil crisis of the 1970s. The locations of possible hydropower basins, denoted by four-letter codes, are shown in Fig.1. Although run-off measurements have been started in all these basins, the measured series are still too short to give a reliable basis for planning. This can be overcome by using run-off climate models to calculate past run-off from climatological data and thereby to extend the measured series (Braithwaite 1984). This involves the calculation of specific run-off which is then integrated over the whole area of the drainage basin to give the run-off volume. The purpose of the present paper is to point out that there can be problems in determining areas of hydrological basins in Greenland, and that remote-sensing data are useful for solving these problems.

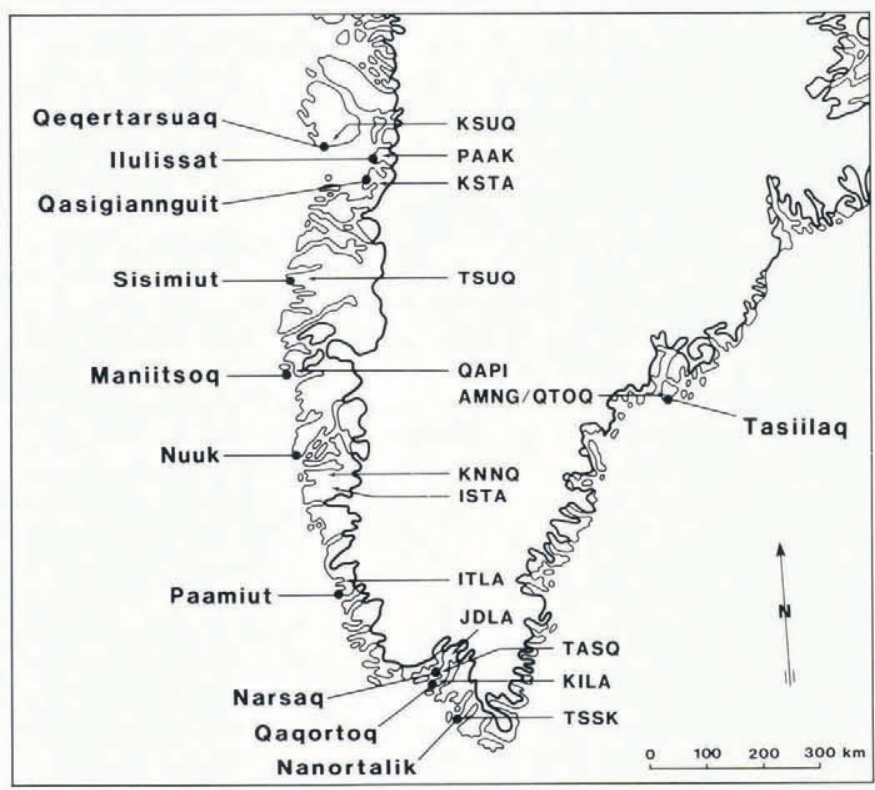

Fig.1. Basins in Greenland where hydro-electric power might be developed.
Most of the basins shown in Fig.1 are conventional hydrological basins bounded by impervious bedrock and there are no serious problems in delineating their boundaries using available topographic maps. However, four of the basins, i.e. PAAK, KSTA, ISTA, and ITLA, contain sectors of the inland ice sheet which makes it difficult to delineate their boundaries because drainage occurs on, within, and under the ice. The surface topography of the ice sheet is poorly mapped, making it difficult to determine the surface-drainage pattern, while the subglacial topography is generally unknown so that it is impossible to determine the englacial and subglacial drainages. The existence of large errors in drainage-basin areas can be illustrated by the results of run-off calculations for the PAAK and KSTA basins which were made at the start of the present project using surface contours from the available maps, i.e. the $1: 1000000$ ICAO and 1:250000 Danish Geodetic Institute map series. The calculated run-off for the two basins over-estimated the measured run-off by 121 and $81 \%$, respectively (Braithwaite and Thomsen 1984[a], [b]). As described below, these results were very much improved subsequently by the use of remote-sensing information.

\section{DRAINAGE CONDITIONS AND THE NEED FOR DATA}

Melting on the Greenland ice sheet generally starts in May and lasts until August or September, with greatest run-off in July to August. The melt water decreases with elevation, mainly due to the decrease of temperature. The first phase of melting at any elevation involves the removal of winter snow cover (if any) followed by the melting of glacier ice. Run-off from melting ice is almost instantaneous while run-off from melting snow may be hindered, or even prevented, in various ways. For example, water from a melting snow surface may be refrozen within or under the snow cover, i.e. as ice lenses or as superimposed ice, so that it will not contribute to run-off. There are also large areas of the ice sheet with relatively gentle slopes where melt water can be stored for shorter or longer times in slush fields and snow-dammed lakes. These tend to lie around the transient snow line and move to progressively higher elevations with time. Drainage areas on the ice sheet therefore increase with time and have their maximum extent at the end of the summer.

After the winter snow cover has been melted away, melt water drains through a system of rivers on the ice surface which generally follows hollows on the of ten strongly undulating surface. In some cases, rivers run in canyons up to $6 \mathrm{~m}$ deep which cut through local ridges on the surface and can even lead the water against the trend of surface topography. Rivers sometimes run on the surface directly to the ice margin but more often the melt water disappears into the ice through moulins or crevasses several kilometers from the ice margin. The surface drainage therefore depends on the general surface topography, local surface topography reflecting subglacial topography, and structural features such as shear bands, healed crevasses, and ridges indicating the ice-flow pattern.

The melt water drainage within and beneath glaciers is very difficult to study because of the inaccessibility of this 
environment. Björnsson (1982) described a theory for subglacial drainage which shows that water flows down the gradient of hydraulic potential which depends upon both surface and subglacial topography, so that marked ridges and valleys under the ice also influence the drainage pattern.

Detailed maps of surface and subglacial topography are therefore needed for a description of the overall drainage pattern and a delineation of drainage areas.

\section{DRAINAGE-BASIN DELINEATION BY REMOTE \\ SENSING}

Detailed mapping of surface and bottom topography over large areas of the inland ice sheet would be a timeconsuming and expensive process beyond the limits of the present project. However, remote sensing offers a quick and cheap way to extract some of the information needed for improved run-off simulations. For example, Landsat MSS data recorded under conditions of low Sun angle have been used in glacier-covered areas to map surface features which reflect the subglacial topography (Krimmel and Meier 1975; Thorarinsson and others 1973).

For the present study, digital Landsat MSS data recorded late in the melt season were chosen. The image processing was done at the DK.IDIMS facility at the Electromagnetics Institute, Technical University of Denmark. The data analysis included geometrical correction and enhancement to increase the contrast ratios in the images so that individual surface features can be more clearly differentiated (Thomsen 1983[a], [b]). The data were plotted on an Applicon ink plotter to give Landsat-image maps which were used for interpretation and later plotting of maps of surface features (Thomsen 1986). These maps show surface features related to ice and melt-water drainage as well as the local topography which reflects the subglacial topography.

So far, maps of surface features have been made for the PAAK, KSTA, and ISTA basins (Thomsen 1983[b]). In all three cases they led to a radical change in the basin delineation. This is illustrated by Fig.2, which shows the delineation of the KSTA basin before (top figure) and after (bottom figure) taking account of information from the surface feature map. The large-scale contour lines in the two cases are identical.

The above example shows that the hydrological drainage area is smaller than first thought. However, there is still an element of subjectivity in inferring the direction of drainage and hydrological boundaries, i.e. signatures (7) and (8) in Fig.2, from the surface feature information, i.e. signatures (3) to (6). Two different estimates of drainage area, corresponding to maximum and minimum estimates, were therefore mades and used as input data for further run-off simulations.

\section{RUN-OFF SIMULATION}

Simulations of run-off are made by calculating specific run-off and then integrating it over the presumed area of the drainage basin to give the run-off volume. The specific run-off at various elevations is calculated from temperature and precipitation data which are extrapolated from long-term climate stations on the coast of Greenland: Ilulissat for the PAAK and KSTA basins, Nuuk for the ISTA basin, and Paamiut for the ITLA basin. The calculations are made separately for glacier-covered and glacierfree conditions by the MB1 (mass-balance) and SM1 (snow-melt) models of Braithwaite (1984). Results from the two models are then passed into a third model which calculates the total run-off from the basin after the elevation distributions of glacier-covered and glacier-free areas within the basin have been specified.

The details of how to calculate specific run-off from climate data using the MB1 and SM1 models are beyond the scope of the present paper as they have been briefly discussed by Braithwaite (1984) and in Braithwaite and Thomsen (1984[a], [b]), and will be fully described elsewhere. The point of the present discussion is that the calculated run-off volume is sensitive to assumptions about the distribution and total amount of ice cover in basins
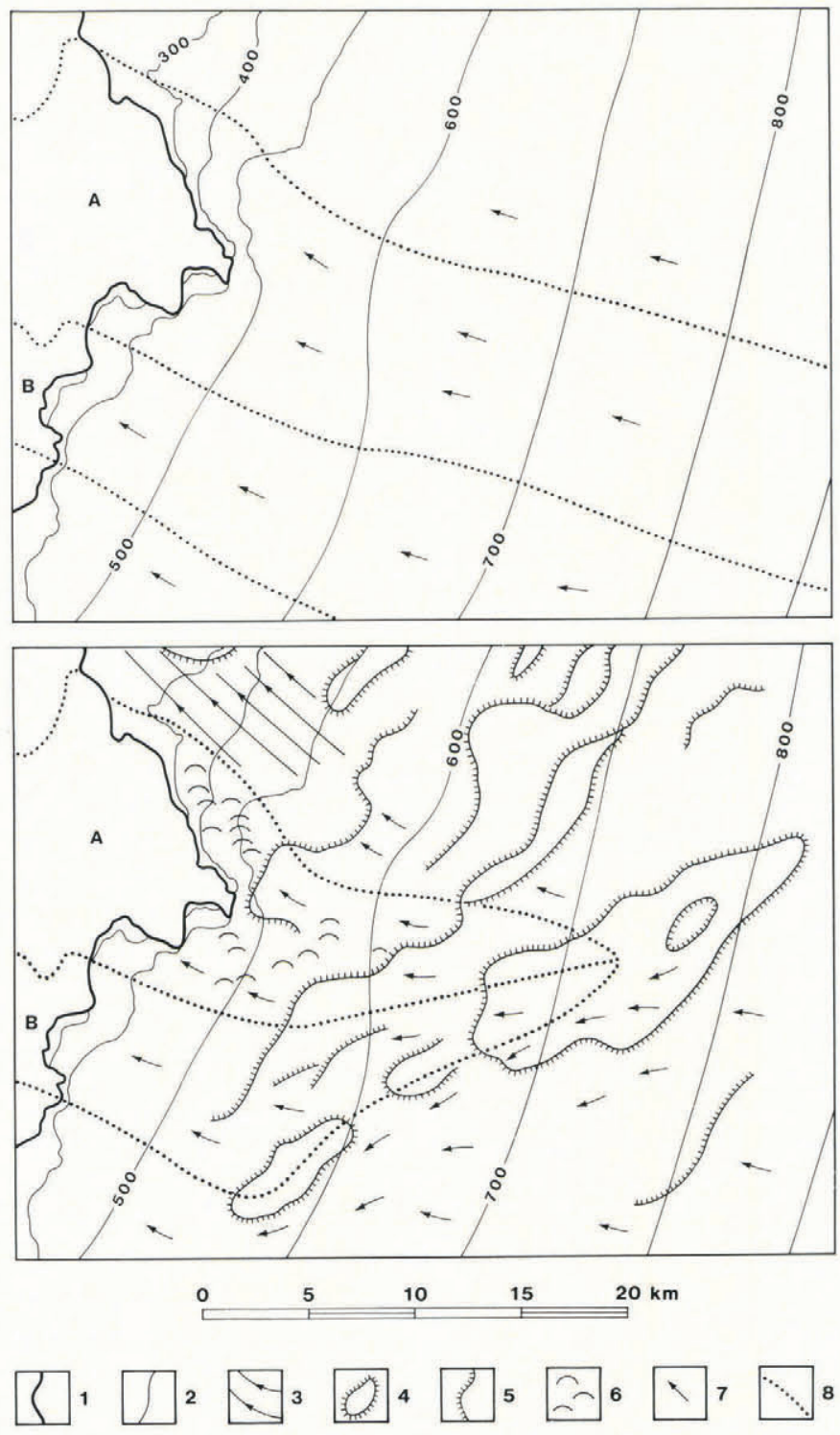

Fig.2. Sketch map showing the marginal part of the Greenland ice sheet draining to the ice-free areas $A$ and B. The upper map shows basin delineation based only on a large-scale surface topography. The lower map shows drainage-basin delineation also taking into account inferred subglacial topography. (1) Ice margin, (2) contour line, (3) flow lines, (4) marked positive relief, (5) marked change in slope, (6) undulating terrain, (7) inferred direction of melt-water drainage, (8) inferred hydrological boundary.

including sectors of the ice sheet. This is illustrated by Fig.3, which shows the relation between calculated run-off and assumed area of the PAAK drainage basin. There are two curves corresponding to different estimates of the degree-day factor used to calculate ablation from temperature (Braithwaite and Olesen 1985).

The curves in Fig. 3 are constructed by making run-off simulations for different versions of the PAAK drainage basin; the original version based only upon large-scale contours and the maximum and minimum estimates based upon the remote-sensing information. The climate data used in this case are the averages for the period 1980-84 for which the run-off from the basin has been measured. The measured annual run-off for the 5 years is on average 280 $\mathrm{x} 10^{6} \mathrm{~m}^{3}$ which, according to Fig.3, corresponds to a basin area of between 380 and $200 \mathrm{~km}^{2}$. These hydrologically based estimates are in rough agreement with the maximum and minimum estimates of the basin area using remote-sensing data, i.e. 395 and $265 \mathrm{~km}^{2}$, and are much less than the original delineation with an area of $788 \mathrm{~km}^{2}$.

The remaining uncertainties in the size of drainage 


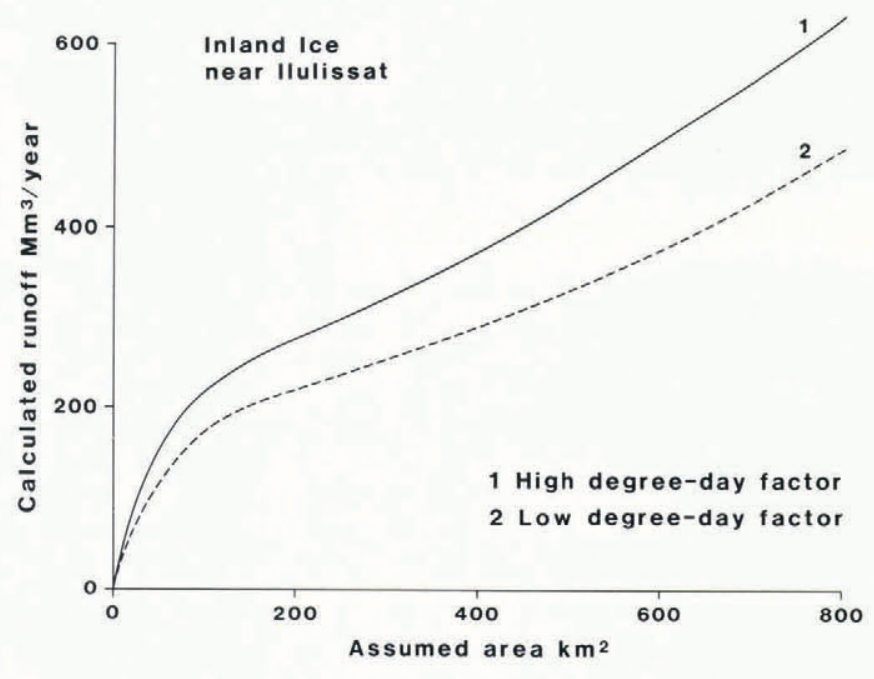

Fig.3. Relation between calculated annual run-off and assumed drainage area for the PAAK basin, Ilulissat, West Greenland.

basins on the ice sheet can be overcome by calibrating the run-off model with the few years of measured run-off data and then using the calibrated model to reconstruct past variations in run-off (Braithwaite and Thomsen 1984[a], [b]). However, this reconstruction assumes a static relation between climate and run-off which may not be true. For example, if the present retreat of the ice margin continues, the ablation area of the basin will get smaller and there may also be a diversion of the drainage pattern.

\section{WORK IN PROGRESS}

Work is now in progress to improve the delineation of drainage basins on the ice sheet and to assess the possibilities of future changes. For example, previous work involved the inference of bottom topography from low Sunangle Landsat images, while the present programme includes the direct measurement of bottom topography by electromagnetic reflection (EMR) techniques. Despite some initial problems (Thomsen and Madsen 1985), detailed profiles of ice thickness have now been measured in the PAAK basin by Thorning and others (1986). The measurements were made with a $300 \mathrm{MHz}$ radar (developed by the Electromagnetics Institute, Technical University of Denmark) mounted in a small helicopter.

The EMR results are still being analysed but it is planned to make a map of subglacial topography which, combined with an improved map of surface topography by Thomsen (1986), will be used for calculation of hydraulic potentials following the method of Björnsson (1982). This should give a more objective basis for drainage-basin delineation than the method used at present. It may also be possible to extrapolate the present thinning of the ice margin into the future to see whether the drainage-basin delineation will change.

\section{ACKNOWLEDGEMENTS}

This paper is published by permission of the Director, the Geological Survey of Greenland. The work is a contribution to investigations of hydro-electric power in Greenland and was partly funded by the European Economic Community (EEC) through the European Regional Development Fund. The digital image processing was done at the DK.IDIMS facility, Electromagnetics Institute, Technical University of Denmark. The Electromagnetics Institute also loaned a $300 \mathrm{MHz}$ radar set which was operated by Leif Thorning and Egon Hansen of the Geological Survey of Greenland.

\section{REFERENCES}

Björnsson H 1982 Drainage basins on Vatnajökull mapped by radio echo soundings. Nordic Hydrology 13(4): 213-232
Braithwaite R J 1984 Hydrological modelling in Greenland in connection with hydropower. Gronlands Geologiske Undersogelse. Rapport 120: $90-94$

Braithwaite R J, Olesen O B 1985 Ice ablation in West Greenland in relation to air temperature and global radiation. Zeitschrift für Gletscherkunde und Glazialgeologie 20, 1984: 155-168

Braithwaite R J, Thomsen H H 1984[a] Runoff conditions at Kuussuup Tasia, Christianshåb, estimated by modelling. Grønlands Geologiske Undersøgelse. Gletscher-hydrologiske Meddelelser $84 / 2$

Braithwaite R J, Thomsen H H 1984[b] Runoff conditions at Paakitsup Akuliarusersua, Jakobshavn, estimated by modelling. Gronlands Geologiske Undersogelse. Gletscher-hydrologiske Meddelelser 84/3

Krimmel R M, Meier M F 1975 Glacier applications of ERTS images. Journal of Glaciology 15(73): 391-402

Thomsen H H 1983[a] Glaciological applications of Landsat images in connection with hydropower investigations in West Greenland. Proceedings of the EARSeL/ESA Symposium on Remote Sensing Applications for Environmental Studies. ESA Special Publication 188: $133-136$

Thomsen H H 1983[b] Satellitdata - et redskab til studier af indlandsisens randzone i forbindelse med vandkraftundersøgelser. Gronlands Geologiske Undersogelse. Gletscher-hydrologiske Meddelelser 83/8

Thomsen H H 1986 Photogrammetric and satellite mapping of the margin of the inland ice, West Greenland. Annals of Glaciology 8: 164-167

Thomsen H H, Madsen P S 1985 Radio ekko málinger af indlandsisens randzone $\mathrm{i}$ Disko Bugt omrảdet 1984. Gronlands Geologiske Undersogelse. Gletscher-hydrologiske Meddelelser $85 / 1$

Thorarinsson S, Sæmundsson K, Williams R S Jr 1973 ERTS-1 image of Vatnajökull: analysis of glaciological, structural, and volcanic features. Jökull 23: 7-17

Thorning L, Thomsen H H, Hansen E 1986 Geophysical investigations over the margin of the inland ice at Pâkitsoq. Gronlands Geologiske Undersogelse. Rapport 130? $114-121$ 